\title{
4
}

\section{Schools with SPIRIT - capacity building in The Netherlands}

\author{
Pieter Hogenbirk \\ Sectormanager PRINT \\ PRINT\VO \\ P. O. Box 15922, 3800 BN Amersfoort, The Netherlands \\ Tele + 3133 4534283; Fax + 31334534380 \\ E-mail:P.Hogenbirk@Print.cps.nl
}

\begin{abstract}
For the last 12 years the Dutch government has supported the supply of computers, the development of educational software and the introduction of computers in the schools. Prior to 1993 several attempts were made to train teachers to use IT. In 1993 the PIT project used the strategy of networking teachers to use software in their own disciplines and encouraged them to develop their own materials. Teachers were also encouraged to share and learn from each other's experiences. Involving more than $50 \%$ of all lower secondary schools, over 2,000 teachers and over 30 curriculum specialists the strategy has relied on the commitment of the schools involved - Schools with SPIRIT - and on a multiplier effect in schools. According to an extensive external evaluation the PIT strategy appeared to be a very effective alternative to 'traditional' in-service training.
\end{abstract}

\section{Keywords}

Informatics, secondary education, networks, national policy, integration

\section{INTRODUCTION}

For 12 years (1985-1997) The Netherlands worked with national projects introducing Information Technology (IT) into secondary education. We will distinguish between the first seven years and the following five years. From 1987 until 1992 an infrastructure of hardware, software and humanware 
resources was installed. After this period the average teacher was expected to use the computer in the curriculum but efforts were disappointing at best and the government decided to put emphasis on helping teachers use the computer as part of their everyday teaching.

For the past five years an ambitious program, the PIT project (PIT is an acronym for 'Project on Information Technology' but a 'School with PIT' in Dutch also means a 'School with Spirit') has been carried out to implement IT in lower secondary education. 1989

From 1986 - 1989 the New Information Technology for Secondary Education (NIVO), a national project for secondary education, was initiated. All secondary schools received 11 IBM-compatible computer configurations, 8084 XTs, a package of software tools - mainly application software - and obligatory training for at least three teachers per school in information literacy. Many teacher training courses, offered on a voluntary basis, were also developed and carried out. At the same time the development of educational software began under the motto 'Let thousand flowers bloom' and work began on the development of curricula in which IT is treated as an objective.

NIVO resulted in the de facto standardization of computer hardware in schools (Collis and De Vries, 1993) and gave an impetus to courseware development (Collis and Moonen, 1995). The project also started the process of changing existing curricula (Hall, Loucke and Rutherford, 1977). Almost 95 $\%$ of the schools actually did organize courses in information literacy. Above all, the project provided conditions to orient schools and teachers to the possibilities of IT and so IT became part of the agenda for most of the schools (Hogenbirk and Diepeveen, 1993). 1989 - 1993

From 1989 until 1993 PRINT, the PRoject on the Implementation of New Technologies, was designed to continue the introduction of computers into education. PRINT is a temporary project organization, with the assignment to manage and coordinate all the national initiatives for Information Technology and education. The management team consists of 9 people, all from different institutes.

A new curriculum on aspects of informatics in physics, social science, economics, mathematics and Dutch (mothertongue) was completed.

Courseware to be used year-by-year through the existing curriculum of school subjects was developed. A major research project on three pilot schools was conducted to obtain information about successful introduction strategies, resulting in trials of many activities introducing computers into classrooms.

The activities were designed for all schools in regional projects with support of the National Educational Advisory Centers. They were also designed for 
The activities were designed for all schools in regional projects with support of the National Educational Advisory Centers. They were also designed for school managers by presenting strategies for planning the introduction of computers in their schools. Teachers in several disciplines received in-service training on the subjects of informatics and Information Technology.

Activities were also targeted at individual teachers who attended a single afternoon session devoted to learning one or more computer-assisted learning (CAL) packages, At the sessions they also learned to implement courseware to be used on a long-term basis throughout the curriculum.

The entire educational community received assistance in IT implementation through articles, written publications, posters, conferences and a help desk. At the same time sufficient courseware to cover large areas of the existing curricula was developed (Collis and De Vries, 1993) and objectives for IT implementation in school subjects were proposed (Collis and Moonen, 1995). The activities generated a great deal of experience in the use of computers (Hall, Loucke and Rutherford, 1977; Hogenbirk and Diepeveen, 1993) but expectations had been too high. The 'ship of education' is very large and hard to get moving. By 1993 the incidental use of IT as a tool in the daily practice of education was limited to a few teachers in a few subjects in a minority of schools (Pelgrum, Janssen Reinen and Plomp, 1993).

THE THIRD PHASE OF THE NATIONAL POLICY 1993 $-1997$

In 1993 the Dutch government asked PRINT to initiate a project designed to help teachers in lower secondary classrooms use IT. The project was to last from 1993 to 1996 . The scope was subsequently broadened to involve Communication Technology (ICT). The plan, designed for all students from 12 to 15 , was introduced in 1993 and called for the project to become part of the new curriculum, called 'Basic Education'.

PRINT launched the Project on Information Technology (PIT) (Veen, Hogenbirk and Jansen, 1994). PRINT initiated three rounds of project participation (March 1993, March 1994 and September 1995) and invited every secondary school to compete for projects in three out of eight school subjects: Dutch (mothertongue), German, French, English, mathematics, physics and chemistry, biology and technical skills. In each discipline there was a choice of one out of four or five themes. PRINT chose the most promising schools and tried to honour their preferences for the subjects and themes as much as possible.

Table 1 shows a sample of the themes that teachers might work on with colleagues from other schools. 
Table 1 Brief description of themes in the PIT project.

\begin{tabular}{|c|c|c|}
\hline Subject & Theme & Goal \\
\hline \multirow[t]{2}{*}{$\begin{array}{l}\text { Dutch } \\
\text { and }\end{array}$} & Theme 1: Learning problems & $\begin{array}{l}\text { Using IT to remedy learning } \\
\text { spelling problems. }\end{array}$ \\
\hline & $\begin{array}{l}\text { Theme 2: Differentiation in time } \\
\text { and contents in the } \\
\text { classroom } \\
\text { Practice }\end{array}$ & $\begin{array}{l}\text { Using IT to stimulate } \\
\text { differentiation in time } \\
\text { and contents among pupils in } \\
\text { classroom practice. }\end{array}$ \\
\hline $\begin{array}{l}\text { English } \\
\text { pupils }\end{array}$ & Theme 2: Study skills & $\begin{array}{l}\text { Teaching and developing } \\
\text { to concentrate by } \\
\text { means of IT. }\end{array}$ \\
\hline French & $\begin{array}{c}\text { Theme 1: Computer-assisted } \\
\text { instruction }\end{array}$ & $\begin{array}{l}\text { Using software that offers } \\
\text { considerable potential to } \\
\text { realize the core objectives in } \\
\text { French. }\end{array}$ \\
\hline German & Theme 1: Remediation & $\begin{array}{l}\text { A number of programs are to } \\
\text { be demonstrated, tested in } \\
\text { the classroom and evaluated, } \\
\text { in each case emphasizing the } \\
\text { remediation possibilities of } \\
\text { the package. }\end{array}$ \\
\hline Mathematics & Theme 1: Algebra and Statistics & $\begin{array}{l}\text { A wide range of software } \\
\text { may be applied when } \\
\text { learning to process } \\
\text { statistical data or to interpret } \\
\text { and represent algebraical } \\
\text { relations. }\end{array}$ \\
\hline geometry classes & Theme 2: Geometry & $\begin{array}{l}\text { The evaluation, } \\
\text { adaptation and } \\
\text { implementation of } \\
\text { software for } \\
\text { in the new }\end{array}$ \\
\hline $\begin{array}{l}\text { curriculum } \\
\text { as 'Mathematics } \\
16 \text { ' }\end{array}$ & & $\begin{array}{l}\text { referred to } \\
\text { from the age of } 12 \text { to } \\
\text { will occur. }\end{array}$ \\
\hline
\end{tabular}


The PIT schools were given incentives to participate, including free counseling and help with the implementation of technology. In rounds one and two they also received 24000 guilders (about $\$ 12000$ ) per year to spend on hardware and software. The funds also paid for extra hours for the teachers involved in the project. In round 3 the money supplied by the government was limited to the organization of the project and the actual support of the teacher networks. Schools participating in round three had to fund all the other expenses themselves.

Interest in the PIT project was overwhelming. For the first and second rounds more than 500 schools applied and 125 schools were selected for the first round starting in 1993; in 199471 schools were selected for the second round; in round three 230 schools applied (and that was amazing given that the schools had to finance a large portion of the activities themselves) and all were allowed to participate.

Schools were selected for the project on the basis of their letters stating the school's motives for joining the project. Commitment of the school administration, equipment available and the level of teachers' involvement were also criteria used to select schools.

Over the three rounds 77 teacher networks - theme groups - were formed, each consisting of one or two teachers from one or more subjects from approximately 15 schools. Each teacher network tackled one of the themes defined for its discipline. The networks met face to face six times in a school year.

The participating teachers were instructed and coached by theme group leaders from three national Educational Advisory Centers. Teachers exchanged information and professional insights, and worked on their personal and professional development. They also developed, commented on and evaluated new materials. Each PIT school was encouraged to participate in at least three networks in three different subjects in order to get a critical mass of IT users in every school. Each participating school had to appoint a PIT coordinator to manage the project at the school by giving support, and assisting in the making and implementation of school policy on IT.

School administrators signed a contract specifying the duties of PIT and the schools. The PIT coordinators and a member of the administration of each PIT school attended special sessions about project approach, implementation support and policy making during the course of the project.

\section{EVALUATION OF THE PROJECTS}

In order to monitor the project but also to evaluate the process of change in the schools and among their teachers, a evaluation plan was devised. With the wide range of activities going on in the PIT Project, three different sources of information were used: (1) the PIT coordinators, (2) the PIT teachers and (3) the theme group leaders. The evaluation for the first two rounds was carried out by the Faculty of Educational Science and Technology, Department of 
Instrumentation Technology (ISM) of the University of Twente in The Netherlands (Collis and Moonen, 1995). The framework of the ConcernsBased Model (CBAM) (Hall, Loucke, and Rutherford, 1977) was chosen as a framework for assessing two major aspects of the project: the degree to which the PIT teachers moved to higher levels of IT use in instruction during their participation in the PIT project and the degree to which a multiplier effect occurred in the PIT schools - i.e., did other teachers not directly participating in the PIT Project also move to higher levels of IT use according to the CBAM Model.

The CBAM Model as modified for teachers' reactions to computer-related innovations (Collis and De Vries, 1993) is shown in Table 2.

Table 2 CBAM Model Adapted for IT Use

Level of the CBAM model

1. minimal awareness level

2. some knowledge

3. some use of one or two types

4. regular use

5. regular use and leadership role
Action toward the innovation

1. casual interest in getting information about the innovation

2. interest in browsing and exploring

3. tries some things in practice

4. makes some uses of IT routine in his/her instructional setting

5. makes regular use of IT in instructional practice and also works in various ways to stimulate his/her colleagues to also make use of IT

(Hall, Loucke and Rutherrord, 1977)

The increased use of IT by the PIT teachers in their classrooms was a major outcome of the project. Data showed a significant increase in teachers' selfreported CBAM levels - from 2.57 at the start of the project in September 1993 to 3.73 at the conclusion of the project in May, 1995 (Hogenbirk, 1996).

PIT-coordinators were asked to indicate their assessment of the satisfaction of the PIT teachers with the project. The majority of the teachers were 'mostly satisfied' with the project and only a small constant percent of teacher was 'mostly negative'. In a setting where so many teachers of different backgrounds, different starting points of IT experience and different expectations on the personal were a factor outcome of the project the results are reassuring. A slight decrease in satisfaction in round 3 is assumed to be related to the fact that the evaluation took place in the middle of that project year and 
the third round consisted of only six meetings of the theme groups so there was less time for the teachers to get as involved as the participants of rounds 1 and 2.

Two sets of indicators were used to evaluate the multiplier effect of the project in the participating schools. The PIT teachers reported a significant change in the level of IT use by their non-PIT colleagues - from CBAM level 1.96 at the beginning of the project to 2.74 by May 1995 . A majority of the PIT coordinators (70\%) stated that an increase in IT use by non-PIT teachers had occurred and another $18 \%$ stated that the increase was growing (Collis and Moonen, 1995).

Encouraging groups of teachers to meet regularly and work together to explore a theme in their subject appears to be a powerful strategy for changing attitudes towards new types of educational behaviour- specifically toward IT. Important elements in the plan to change teachers' perceptions and activities for IT use include creating a critical mass of experts - teachers and others - in the schools, ensuring that sufficient software and hardware is available in the classrooms, and gathering teachers on the base of common interests and similar levels of IT expertise. Experience has also shown us that IT innovators must put an emphasis on the professional development of the teachers - especially on their exchanges of experiences - and projects must facilitate teachers directly as well as through the commitment and efforts of the school administration.

In our experience teachers' increased use of IT for classroom work will occur when there is a balanced mix of easy-to-use materials and less easy-to-achieve but important improvement of teaching methods through training and information exchanges among teachers. The members of the teacher networks must have the opportunity to call on help and support during the project as well as after the conclusion of the project, and project staff must make sure that physical face-to-face meetings occur to build a cooperative supportive group, continuing to support the cooperation - if possible - through the Internet. Of course the whole setup of the PIT project demands great human, infrastructural and financial resources. For other countries and situations select elements of the project suited to the local situation and conditions may prove to integrate learning to use IT with the teaching/learning process.

\section{REFERENCES}

Collis, B., \& De Vries, P. (1993) The Emerging Trans-European Network for Education and Training: Guidelines for Decision Makers. Commission of the European Community, Task Force Human Resources, Education, Training and Youth, Brussels.

Collis, B. \& Moonen, B. (1995) The PIT Project: Final Evaluation Report. Faculty of Educational Science and Technology, University of Twente, Enschede, The Netherlands. 
Hall, G., Loucke, H., and Rutherford, W. (1977) Measuring stages of concern about an innovation. University of Texas Research and Development Center for Teacher Education, Austin, TX.

Hogenbirk, P. (1996) The PIT-project: A teacher networking approach for broadscale use of ICT, in Information Technology: Supporting Change through Teacher Education (eds. Don Passey and Brian Samways), Chapman \& Hall, London.

Hogenbirk, P. and Diepeveen, T. (1993) Towards an information society: The policy of changing education in the Netherlands, in Informatics and Changes in Learning (eds. D.C. Johnson and B. Samways), Elsevier Publishers, Amsterdam.

Pelgrum, W.J., Janssen Reinen, I.A.M. and Plomp, Tj. (1993) Schools, Teachers, Students and Computers: A Cross-National Perspective. IEA, The Hague.

Veen, W., Hogenbirk, P. and Jansen, F. (1994). The Implementation of Communication and Information Technologies in Teacher Education in the Netherlands, in Workshop Teacher Education and Communication and Information Technologies: Issues and Experiences for Countries in Transition. University of Twente, Enschede, The Netherlands.

PRINT. (1994) PIT, Projects on Information Technology, English version, available at the PRINT office, P. O. Box 1592, 3800 BN Amersfoort, The Netherlands.

BIOGRAPHY

Pieter Hogenbirk has been a teacher in secondary education. In 1987 he became project manager for the NIVO project and from 1989 he served as project manager of the PRINT project, coordinating the development and implementation of curricula, assessment, courseware and teacher training. He was the first chairman of the Dutch Society of Informatics Teachers. From 1993 he has been head of the PRINT management, with supervision of more than 100 ICT projects. Among these the PIT project was the largest. In 1996 he also became chairman of a consortium for developing a study planning and registration tool, and the Dutch government has assigned him to inaugurate the Dutch National Educational Network. 